\title{
Followership among UK Secondary School Teachers
}

\author{
Andrew Francis \\ University of Hertfordshire \\ England, United Kingdom
}

\begin{abstract}
This paper reports the preliminary findings of an exploratory study which investigates the followership of longstanding, classroom-based school teachers working in the UK secondary education sector. Using Gronn's (1999) educational leadership formation model as a frame of reference, the study employs a multiple case study methodology with data collected using semistructured biographical interviews and Kelley's (1992) followership questionnaire. Focusing on those individuals that have not embraced a formal leadership or management role as part of their teaching career (teacher-followers), the study investigates how these teachers follow and how the characteristics of their life and career have influenced their followership journey. The preliminary findings indicate that followership is characterised by two of Kelley's five classifications, i.e., pragmatic and exemplary followers. Further, the reported experiences and influences of the teacher-followers in the formative stages of their career are aligned with those reported for teacher-leaders (Ribbins, 1997; Gronn, 1999; Inman, 2007; Mackensie-Batterbury, 2012). Finally, self-belief and confidence; opportunity to lead; and pragmatism are reported as differentiating factors in shaping the nature of the career journeys of the teacher-followers engaged in this study.
\end{abstract}

\section{Introduction}

Kelley (1992) observed, "Followership dominates our lives and organisations, but not our thinking, because our preoccupation with leadership keeps us from considering the nature and importance of the follower" (p. 143). Today, while the fixation with the leader continues, the 
study of followership is well established as a research topic in its own right; one described by Bligh (2011) as "an emerging critical, even 'controversial' stream of theorizing and research that has provided an alternative to the mainstream leadership tradition" (p. 426).

Scholarly research largely focused on leaders and ignored followers until researchers such as Kelley (1992), Hollander (1992), and Chaleff (1995) began to demonstrate the importance of followership. Prior to their pioneering work followers were often portrayed as either "blindly and passively obedient or defiant and insubordinate" (Carsten, Harms, \& UhlBien, 2014, p. 3). Hollander's (1992) summary of the situation observed that the leader-follower relationship was affected by "perceptions, misperceptions, and self-oriented biases" noting that few scholars were examining how followers might contribute actively and positively within the leadership process (p. 43).

Today, followership researchers often see leadership as a process that is co-created in social and relational interactions between people (Fairhurst \& Uhl-Bien, 2012; Uhl-Bien, Riggio, Lowe \& Carsten, 2014). Consequently, attention has shifted from how an individual interacts in their work role and with co-workers, to how he or she behaves in relation to their leader and the impact that this has on organisational success.

\section{Research Purpose and Questions}

This study explores how and why longstanding, classroom-based secondary school teachers follow. It investigates the key influences on the lives and careers of teacher-followers to better understand how they have shaped the participants' followership journey. The three research questions below are considered central to the study:

1. How do longstanding, classroom-based secondary school teachers follow?

2. What characteristics of their life and career have influenced their teaching journey? 
3. Why does the absence of formal leadership responsibilities feature within their teaching journey?

\section{Theoretical Framework}

Some of us want to be leaders. Others are content to be followers. We make choices, or at least we like to think we do. How and why it is that particular choices in respect of leadership and followership come to be made throughout our lives, and what parameters and confines within which those choices are made, are part and parcel of leadership careers. (Gronn, 1999, p. 20).

To better understand the interplay between agency and structure and how this impacts the choices we make, Gronn (1999) proposed an educational leader formation model consisting of four phases through which educational leaders progress. The first stage of the model, formation, is concerned with early stage influences on individuals, from childhood to adulthood. The second stage, accession, is where a teacher develops a range of skills and experiences in preparation for headship. The third stage, incumbency, refers to the period of employment as a head teacher, while the fourth stage, divestiture, refers to the final stage of the leader's career, where ultimately they step out of the headship role. This longitudinal, contextually-driven model is a framework used to provide a collection of multiple realities and a window into how the participants' careers have been shaped by the historical, cultural and societal context in which they have lived and worked.

\section{Research Design}

The ongoing study upon which this paper is based uses a case study methodology which is well-suited to an empirical investigation of followership; it provides a detailed contextual 
analysis of a number of events or conditions and their relationships (Denscombe, 2010, p. 53).

The primary data collection tool is the semi-structured biographical interview. Data drawn from interviews is further supplemented via the completion of Kelley's (1992) followership questionnaire which provides a useful touch point for followership discussions.

The study aims to reveal information on teacher followership that may not come to light through a research design that attempts to cover a large number of instances such as a survey approach. Further, it seeks to gain sufficient detail to unravel the complexities of how and why the participating teachers follow.

\section{Research Participation and Sampling}

A purposive sampling method was used to access the classroom-based, secondary school teachers. Participants were required to have been teaching for at least seven years and to have held no formal leadership or management role during their career. Participants willing to be involved in the study were invited to do so by their school's head teacher. Once recruited, they assisted in locating other candidates for involvement in the study - a snowballing technique that is a legitimate research practice when studying hard to reach groups (Denscombe, 2010). The findings reported here reflect the experiences of eleven participants $(n=11)$; seven females and four males. The age profile ranges from teachers in their late twenties to those in their sixties. The average length of teaching is 16 years and participants were drawn from five secondary schools and a variety of teaching subjects.

\section{Data Collection and Analysis}

Data was collected primarily through semi-structured, biographical interviews.

Participants were briefed on the principles of informed consent and this was gained in each case 
before the interview began. Held at the participants' schools, the interviews were recorded and typically lasted 90 minutes. Interview questions were scripted and structured to encourage participants to discuss their approach to following (e.g., Tell me about your relationship with your line manager; How do you make decisions?) and to consider how the characteristics of their life and career have influenced their teaching journeys (e.g., Tell me about the experiences and encounters in your early years that may have influenced your decision to become a teacher). Kelley's Followership Questionnaire (1992) is a simple, self-report style questionnaire which proposes two dimensions that encompass followership styles based on two aspects: their thoughts and their actions. From this, Kelley (1992) identifies five different styles of followership. In this study, participants completed Kelley's (1992) questionnaire at the close of the interview and results were used as a point of reference regarding the applicants' approaches to followership.

After each meeting, the interview was transcribed and additional notes taken during the interviews were documented. The qualitative data analysis software, NVivo, was used to facilitate the process of interpretation. A priori coding was driven from the body of work that describes leadership formation in the UK's secondary education sector (e.g. Gronn, 1999; Ribbins, 1997, 2003) and augmented with codes generated by the data.

\section{Findings}

\section{Q1. How do longstanding, classroom-based, secondary school teachers follow?}

Of the five styles of followership identified in Kelley's (1992) questionnaire - i.e. passive; conformist; pragmatist; alienated and exemplary - the 11 participants were identified as either pragmatic $(\mathrm{n}=4)$ or exemplary followers $(\mathrm{n}=7)$. Kelley (1992) described pragmatic followers as those that "hug the middle of the road" (p. 117). They will question their leader's 
decision, but not too often or too critically, and perform their tasks, but seldom venture beyond their designated duties. They can be political, use rules to support their preferred way and know how to work the system.

The narratives of the four participants recorded as pragmatic followers included the importance of maintaining a work-life balance and a sense that much of what occurred in their working life was either to enable or protect this balance:

...But sometimes I do feel like I have to manage him (the Head of the Department) otherwise we're not going to get stuff done. You know, he's like, "No, we'll just stay here till 11 o'clock at night" and I'm like, "No, you know, there's easier ways to do it." But he always thinks I'm trying to cut corners but I'm not; I'm just trying to plan and I don't want to, you know, torpedo my weekends.

Participants also discussed how they felt able to negotiate and make deals with their leaders and how they would use rules and regulations to get things done to their satisfaction. All viewed their workplace as unstable and a place of uncertainty. They spoke of their concern over the "state of play" of the UK secondary educational sector, the pressure to perform, and the everincreasing bureaucracy associated with being a teacher. A common theme threaded throughout the interviews was their pragmatic stance, as illustrated in the comment below:

....and they haven't just got to pass, they've got to get A's, right? And I don't buy into that, okay. Now, I have to do it because otherwise I'm going to lose my job and I'm not an idiot, I've got a mortgage, right.

Counterintuitively, while they expressed negativity over a range of issues, the participants were emphatic regarding their enthusiasm to work with children; to pass on their knowledge and to prepare them for the world of work. In addition to taking this literally, at least two perspectives could be supported by the data, i.e., the provision of socially desirable answers (could a teacher say that they disliked children?) and cognitive dissonance; where having spent a large part of their life devoted to becoming educated and trained and then 
teaching, deep down they think they really should have done better. Of course, this then would contradict with their self-image as caring, dedicated professionals. Might it be that the pragmatists resolve such dissonances by deluding themselves, saying "Really it's all about the kids, that's why I'm in this job?"

According to Kelley (1992) exemplary followers exercise critical thinking, independent of the leader, and are seen as their own person (p. 126). They do not accept the leader's decision without their own independent evaluation of its soundness. Exemplary followers are seen as able to think for themselves and are committed to the cause. A strongly expressed point of discussion common to these participants was their preference to stay in the classroom. They provided compelling explanations for this which centered on their desire to work with children and to make a difference in their lives. A number of the teachers spoke so passionately on this subject that it strongly reinforced the notion of teaching as a vocation.

The seven participants that self-reported as exemplary followers displayed many of the characteristics expressed by Kelley (1992) as typical of this approach to followership. For example, the respondents were well-connected within the school and in a number of cases linked to professional practice in the wider educational community. All of the respondents expressed competency as teachers and described themselves as professionals. While the respondents considered the job of the classroom teacher as having the same importance as others working in the school vis-à-vis achieving the school's mission, a number felt that this was not reciprocated. They also expressed frustration with those managers they considered less competent than them and felt a sense of duty to challenge their manager or even the school's leadership team when they felt strongly over issues of concern. The quote below demonstrates a number of the 
aforementioned points in quite an extreme manner when describing her relationship with her Head of Department:

....Well on paper, she's above me obviously but I'd describe the level of independence that I have in my role as $100 \%$. We don't make decisions jointly. So how does that work then? I make my own decisions, she makes her own decisions. Or she'll tell me or us that's what's going to happen. I'll decide how I'm going to do things as a result and tell her, or she'll decide how she's going to do things and tell me. How does that work out? If I'm not happy I'll go and moan to her boss (laughs). We work it out (pause) for the kids....I'm very committed to the kids, I'm very committed to the head teacher and his beliefs, not necessarily committed to my department because I don't rate everything that they do. But yeah, it's about the kids, I'm here for the kids.

\section{Q2. What characteristics of their life and career have influenced their teaching journey?}

In line with existing research that has mapped UK-based teachers' journeys to leadership (Gronn, 1999; Inman, 2007; Mackensie-Batterbury, 2012; Ribbins, 1997), participants in this study reported similarly diverse, unpredictable and varied routes into teaching. This paper briefly reports on three influences highlighted in the aforementioned research, i.e., the impact of family; early years' encounters; and motivation to teach.

All participants described their parents as working class and most spoke of how they had left school at 16 to seek employment; none had been graduates. Notwithstanding these limitations, most participants described one or both of their parents as capable, bright people that could have achieved more academically had they been given the opportunity. Most felt that their parents had valued education and that this had rubbed off on them; the participants and their siblings were encouraged to study and to aim high when preparing themselves for employment. Most participants came from a stable home and some spoke at length of their parents, keen to present them as role models who had shaped their lives positively. Only two participants did not speak positively about the influence of their parents; one spoke of her parents' indifference to her 
education and the other described her parents' general lack of influence in the key aspects of her formative years.

The early years' encounters influential in their life and career largely revolved around the impact of their own educational experience. Six of them spoke positively about their schooling and each had a story about a favorite teacher who had encouraged them to work hard and to seek success. A minority was less enthusiastic and was unable to find much to speak about that was positive.

In this study, only two of the 11 participants went to university to train to be a teacher directly from school; one came from a family of teachers and was encouraged from an early stage to follow suit; the other commented, "I knew I wanted to be a teacher right from when I was at primary school aged 10." Most were approaching their mid-twenties when they re-trained to become teachers and they described a variety of reasons for doing so, with serendipity as well as strategic intent guiding their decision-making. One participant commented that "It's the last thing in a million years anyone would have expected; it just wasn't on the radar, but I kind of fell into it." In the same vein, another commented:

.....No, God, everyone was as shocked as anything....it was only when someone I worked with was saying about me, you know, it was an off-handed comment, "Oh you'd make a good teacher," that was it, that's the only thing. But no, nobody ever would have considered me being a teacher.

Three mature participants reflected on when they became teachers and referred to a time when, as one described, "Teaching was a respected profession and a credible career." Two of the participants recalled how there had been a shortage of teachers and that they had responded to a national recruitment drive. Many spoke of the conditions of employment, not least the extended holidays, as a key attraction; one explicitly described the draw of teaching as it being "a chance for a job for life". 
In England, graduates are financially incentivized to train as teachers, as undergraduate and postgraduate students can get help with the costs of their teacher training. Further, depending on the teaching subject area, student teachers may be eligible for a training bursary and in some instances, a "golden hello". This has been particularly evident since the introduction of tuition fees in England in 1998 and for a number of participants, this was a sufficient draw for them to side-step their initial career choice and consider teaching.

\section{Q3. Why does the absence of formal leadership responsibilities feature within their teaching journey?}

Participants reported a range of factors that had influenced and shaped their teaching journey - one devoid of traditional leadership responsibilities. All participants highlighted their enthusiasm for working with children throughout the interviews. However, while for some this ultimately determined that their teaching career would not embrace leadership, the participants reported other factors that had influenced their lack of engagement with traditional leadership within their teaching career. For some, it was a pragmatic stance:

....Yes, I don't think I'm committed enough to the extra work that it would entail. And it would be the extra work I don't like, you know, it would be the stuff I hate, it would be more of the stuff I hate and less of the stuff I like. So it would be a bad trade off.

For four of the eleven participants, to enable them to remain in the classroom, they chose explicitly to avoid what one described as "the distractions of leadership". When questioned whether they had aspirations to take on a formal leadership role, comments such as the following demonstrated their reluctance:

No, no, to be a head teacher or like head of department? No way. I didn't go in thinking, oh you know, I really would love to be a head of year or anything like that, no, I don't know, it's almost like I can't explain it, it's almost like it's fate and I was meant to be a teacher. 
For four participants (three female, one male) the decision to prioritize their own children and raise a family was believed to have limited opportunity for them to embrace a formal leadership role. In addition, two participants suggested that leadership opportunity had evaded them as a result of prioritizing their partner's career over their own. All respondents also believed that balancing teaching and family life was difficult and for some, the idea of adding a leadership responsibility to this was perceived as a step too far:

....And it's very difficult to have a family life with the pressures of today's job as a teacher. I have no social life. Once I've gone home, helped out with the kids, put them to bed, I tend to do half an hour work and crash out. From what I can see unless you're young, fresh, have no responsibilities; you will struggle to do well in this job, in this career. This is the main reason that has stopped me from progressing up the ladder because I can't dedicate more time and I wouldn't want to. I think family life is important. And it's a shame.

A further issue raised by four participants who had viewed leadership as a distraction was their perceived lack of confidence regarding them taking on a leadership role. These respondents who had described themselves in line with Kelley's (1992) exemplary follower spoke in a matter-of-fact way about how they believed that were incapable of undertaking such a responsibility, as illustrated in the two independent comments below:

....Managing people, I can manage kids, managing people's different...I don't want to manage people...I couldn't manage people.

....I tell you there's a good few reasons why I stay in the classroom. One, because I love it, I love working with these kids, I like being there for these kids and doing all of that, and the other one of the main reasons, or, probably the most important reason I've never gone for promotion is because I'd probably be quite $\mathrm{s}^{* *}$ tty at it.

\section{Conclusion}

These early stage results suggest that among participants in this study, teacher-follower positioning is characterised by two of Kelley's classifications of followership, i.e., pragmatic and exemplary. Further, the experiences encountered by teachers in their formative years, reported 
as influential in the existing "journey to leadership" research, are similar for both teacher-leaders and teacher-followers. The data suggests that both groups share influences and experiences that result in diverse, unpredictable and varied routes into teaching.

So why, as Gronn (1992, p. 20) suggests, do some of us want to be lead while others are content to follow? Why do some teachers seek out traditional leadership roles and others seemingly avoid them? The preliminary findings reveal that for the participants, the impact of low self-belief and confidence; the lack of opportunity to lead; and pragmatism in the face of the perceived trade-off of becoming a leader, are reported as factors that have determined the nature of their followership journeys. This paper is largely restricted to reporting the preliminary findings. Moving forward, the ongoing study will look to interpret the findings in light of concepts such as cognitive dissonance, the fear of failure and the fear of success.

\section{References}

Bligh, M. C. (2011). Followership and follower-centred approaches. In A. Bryman, D. Collinson, K. Grint, B. Jackson, \& M. Uhl-Bien (Eds.), The Sage handbook of leadership. London, England: Sage.

Carsten, M. K., Harms, P., \& Uhl-Bien, M. (2014). Exploring historical perspectives of followership: The need for an expanded view of followers and the follower role. In L. M. Lapierre \& M. K. Carsten (Eds.). Followership. What is it and why do people follow? Bingley, England: Emerald.

Chaleff, I. (1995). The courageous follower: Standing up to and for our leaders. San Francisco, CA: Berrett-Koehler.

Denscombe, M. (2010). The good research guide: For small-scale social research projects $\left(4^{\text {th }}\right.$ ed.). Berkshire, England: Open University Press.

Fairhurst, G. T., \& Uhl-Bien, M. (2012). Organizational discourse analysis (ODA): Examining leadership as a relational process. The Leadership Quarterly, 23(6), 1043-1062. doi:10.1016/j.leaqua.2012.10.005

Gronn, P. (1999). The making of educational leaders. London, England: Cassell. 
Hollander, E. P. (1992). Leadership, followership, self, and others. The Leadership Quarterly, 3(1), 43-54. doi:10.1016/1048-9843(92)90005-Z

Inman, M. (2007). The journey to leadership: A study of how leader-academics in higher education learn to lead (Doctoral dissertation). University of Birmingham, Birmingham, England.

Kelley, R. E. (1992). The power of followership. New York, NY: Doubleday.

Mackenzie-Batterbury, R. (2012). The journey to academy principalship (Doctoral dissertation). University of Birmingham, Birmingham, England.

Ribbins, P. (Ed.). (1997). Leaders and leadership in the school, college and university. London, England: Cassell.

Ribbins, P. (2003). Biography and the study of school leader careers: Towards a humanistic approach. In M. Brundrett, N. Burton, and R. Smith (Eds.), Leadership in education (pp. $55-73)$.

Uhl-Bien, M., Riggio, R. E., Lowe, K. B., \& Carsten, M. K. (2014). Followership theory: A review and research agenda. The Leadership Quarterly, 25(1), 83-104. doi:

10.1016/j.leaqua.2013.11.007

\section{Author Biography}

Andrew Francis works at Hertfordshire Business School in the UK. He is a Fellow of the Chartered Institute of Personnel \& Development and of the Chartered Management Institute (CMI). Prior to joining the University, Andrew worked in industry having first spent six years as a Helicopter Engineer in the British Armed Forces. He is currently in the final stages of an educational doctorate at the University of Birmingham, UK. 